\title{
Etiologi dan Karakteristik Demam Berkepan- jangan pada Anak di RS Dr. Cipto Mangunkusumo Jakarta
}

\author{
Barry Army Bakry, Alan Roland Tumbelaka, * Imral Chair* \\ * Departemen Ilmu Kesehatan Anak Fakultas Kedokteran Universitas Indonesia RS Dr. Cipto Mangunkusumo \\ Jakarta
}

\begin{abstract}
Latar belakang. Kesulitan dalam mencari penyebab demam berkepanjangan disebabkan oleh banyak faktor terutama karena penyebab yang beraneka ragam. Waktu serta tempat timbulnya penyakit juga turut berperan. Pengetahuan tentang etiologi dan karakteristik penyakit sangat diperlukan karena memudahkan para klinisi dalam menegakkan diagnosis demam berkepanjangan.

Metode. Penelitian deskriptif retrospektif dilakukan untuk mengetahui etiologi dan karakteristik pasien demam berkepanjangan yang dirawat di RSCM. Populasi anak dengan keluhan demam berkepanjangan saat masuk diambil dari data rekam medis sejak Januari 2004 hingga Maret 2007.

Hasil. Angka kejadian pasien demam berkepanjangan di RS Cipto Mangunkusumo 2\% (100 pasien), sebagian besar laki-laki $59 \%$ dan perempuan $41 \%$ kasus. Penyebab terbanyak penyakit infeksi $80 \%$, yaitu infeksi saluran kemih, demam tifoid, bakteremia, tuberkulosis serta otitis media. Sebagian besar pasien berusia di bawah dua tahun $46 \%$ kasus, memiliki status gizi kurang (75\%). Kuman terbanyak yang ditemukan pada biakan darah, biakan urin dan biakan feses berturut turut Staphylococcus epidermidis, Escherichia coli, dan Escherichia coli patogen

Kesimpulan. Kelompok penyakit infeksi merupakan penyebab terbanyak demam berkepanjangan pada seluruh kelompok umur. Anamnesis, pemeriksaan fisis serta pemeriksaan penunjang yang terarah merupakan kunci keberhasilan dalam mencari etiologi demam berkepanjangan. (Sari Pediatri 2008;10(2):83-88).
\end{abstract}

Kata kunci: etiologi, demam berkepanjangan, anak

Alamat Korespondensi:

Dr. Alan R.Tumbelaka, Sp.A(K). Divisi Infeksi dan Penyakit Tropis, Departemen Ilmu Kesehatan Anak FKUI-RSCM, Jl. Salemba no. 6 Jakarta 10430. Tel. 391 4126. Fax. 3907743.

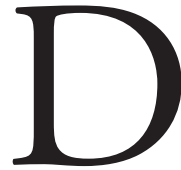

emam berkepanjangan adalah suatu kondisi suhu tubuh lebih dari $38^{\circ} \mathrm{C}$ yang menetap selama lebih dari 8 hari dengan penyebab yang sudah atau belum diketahui. ${ }^{1}$ Angka kejadian dan mortalitas tidak sebesar penyakit lainnya, tetapi masih terdapat masalah dalam menegakkan diagnosis dan mencari penyebab. 
Berbagai penelitian yang dilakukan di dunia tentang penyebab demam berkepanjangan hampir selalu menemukan tiga penyebab terbanyak dari penyebab demam berkepanjangan yaitu infeksi, keganasan dan penyakit jaringan ikat meskipun penyebab spesifiknya dapat berbeda. ${ }^{2,3}$ Kasus infeksi merupakan penyebab terbanyak dari demam berkepanjangan pada anak. ${ }^{1,2}$

Kesulitan dalam mencari penyebab timbulnya demam berkepanjangan disebabkan oleh banyak faktor terutama karena penyebab yang beraneka ragam. Sampai saat ini, lebih dari 200 penyebab demam berkepanjangan yang telah dilaporkan. ${ }^{4}$ Hal ini menyulitkan para klinisi dalam mendiagnosis penyebab demam berkepanjangan dalam waktu yang relatif singkat. Penyebab demam berkepanjangan sering kali berbeda, tergantung wilayah geografi tempat pasien tinggal saat mengevaluasi penyakit yang diderita. Faktor lainnya adalah kecenderungan anamnesis tidak lengkap dan tidak sistematis serta pemeriksaan fisis yang kurang akurat sehingga hal-hal penting yang seharusnya dapat mendukung diagnosis tidak ditemukan. ${ }^{3,4}$

Beberapa penelitian telah dilakukan untuk mengetahui angka kejadian, penyebab serta karakteristik demam berkepanjangan pada anak, namun data tentang angka kejadian terutama penyebabnya di Indonesia masih kurang. Melalui data yang didapatkan akan memudahkan pendekatan diagnosis demam berkepanjangan.

\section{Metode}

Penelitian deskriptif retrospektif untuk mengetahui angka kejadian dan karakteristik demam berkepanjangan pada anak di RS Cipto Mangunkusumo. Populasi terjangkau adalah semua anak usia $>1$ bulan sampai 18 tahun yang didiagnosis dengan demam berkepanjangan di RSUPN Cipto Mangunkusumo sejak Januari 2004 hingga Maret 2007. Subjek penelitian anak yang berusia $>1$ bulan -18 tahun yang didiagnosis dengan demam berkepanjangan baik rawat jalan maupun rawat inap di Departemen Ilmu Kesehatan Anak FKUI RSCM sejak Januari 2004 hingga Maret 2007.

\section{Hasil}

Pengumpulan data penelitian dilakukan secara retrospektif dengan mengambil data dari rekam medik Departemen Ilmu Kesehatan Anak rumah sakit Dr. Cipto Mangunkusumo Jakarta antara Januari 2004 hingga Maret 2007. Selama kurun waktu penelitian didapatkan 100 kasus dengan diagnosis awal masuk rumah sakit demam berkepanjangan yang memenuhi kriteria inklusi dan eksklusi sebagai subjek penelitian.

Di dapatkan 100 pasien (2\%) dari seluruh pasien anak yang di rawat. Penyakit infeksi merupakan penyebab terbanyak yakni 80 anak $(80 \%)$ dari seluruh kasus diikuti dengan penyakit kolagen-vaskular 6 anak (6\%), penyakit keganasan 5 anak (5\%), serta tidak terdiagnosis 9 anak (9\%). Penyebab terbanyak demam berkepanjangan dari kelompok penyakit infeksi adalah infeksi saluran kemih, 23 anak dari seluruh penyakit infeksi. Penyebab terbanyak demam berkepanjangan dari kelompok penyakit keganasan adalah leukemia 4 anak (80\%) dari seluruh penyakit keganasan. Penyebab terbanyak demam berkepanjangan dari kelompok penyakit kolagen-vaskular adalah penyakit

Tabel 1.Distribusi diagnosis akhir penyebab demam berkepanjangan

\begin{tabular}{lll}
\hline Distribusi & $\mathrm{N}$ & $\%$ \\
\hline 1. Penyakit Infeksi & & \\
$\quad$ Infeksi Bakteri & & \\
$\quad$ Infeksi saluran kemih & 23 & 23 \\
$\quad$ Tuberkulosis & 7 & 7 \\
$\quad$ Leptospira & 1 & 1 \\
$\quad$ Demam tifoid & 19 & 19 \\
$\quad$ Bakteremia & 13 & 13 \\
$\quad$ Meningitis bakterialis & 1 & 1 \\
$\quad$ Bronkopneumonia & 2 & 2 \\
$\quad$ Otitis media & 6 & 6 \\
$\quad$ Enterokolitis & 3 & 3 \\
$\quad$ Zoonosis & 1 & 1 \\
Infeksi Virus & & \\
$\quad$ HIV & 1 & 1 \\
$\quad$ Eksantema & 1 & 1 \\
Infeksi jamur & & \\
$\quad$ Kandida & 2 & 2 \\
2. Keganasan & & \\
$\quad$ Neuroblastoma & 1 & 1 \\
Leukemia limfositik akut & 4 & 4 \\
3. Penyakit kolagen-vaskular & & \\
$\quad$ Reumatoid artritis juvenile sistemik & 4 & 4 \\
$\quad$ Lupus eritematosus sistemik & 2 & 2 \\
$\quad$ Tidak terdiagnosis & 9 & 9 \\
\hline & & \\
\hline & & \\
\hline
\end{tabular}


artritis reumatoid juvenil sistemik 4 anak (67\%). Pasien terdiri dari 41 perempuan (41\%) dan 59 lakilaki (59\%). Pada semua kelompok penyebab demam berkepanjangan pasien laki-laki lebih banyak daripada perempuan kecuali pada kelompok penyakit kolagenvaskular.

Pasien termuda berumur 2,5 bulan sedangkan usia tertua 15 tahun. Usia rata-rata pasien 3 tahun 2 bulan. Pengelompokan usia pasien, di bawah usia dua tahun, usia 2 sampai usia 6 tahun serta kelompok usia di atas usia 6 tahun. Berdasarkan pembagian tersebut, kelompok terbanyak kelompok usia di bawah 2 tahun, yaitu 46 anak (46\%) kasus. Kelompok usia antara 2 tahun dan 6 tahun 35 anak (35\%), sedangkan kelompok di atas usia 6 tahun 19 anak (19\%) kasus. Berdasarkan data tersebut terlihat pula bahwa penyakit infeksi merupakan penyebab terbanyak pada masing masing kelompok umur, hanya proporsinya semakin kecil sejalan dengan semakin besarnya usia.

Lama demam berkepanjangan pada penelitian ini beraneka ragam, sebagian besar pasien memiliki lama demam antara 8-30 hari. Lama demam ini paling banyak ditemui pada pasien dengan diagnosis akhir kelompok penyakit infeksi. Sebagian besar pasien memiliki status nutrisi kurang 75 anak (75\%) dari seluruh kasus, gizi baik 20 anak (20\%), dan gizi buruk 5 anak 5\%).

Pemeriksaan penunjang pada pasien dengan demam berkepanjangan terdiri dari pemeriksaan penunjang dasar dan pemeriksaan penunjang lanjutan. Pemeriksaan penunjang dasar yaitu pemeriksaan darah tepi, hitung jenis leukosit, laju endap darah, urinalisa, rontgen dada, serta pemeriksaan serologi HIV. Berdasarkan hasil tersebut didapatkan bahwa pemeriksaan darah tepi dan hitung jenis dilakukan pada semua kelompok penyebab demam berkepanjangan.

Pemeriksaan penunjang lanjutan pada pasien dengan demam berkepanjangan sangatlah beraneka ragam. Berdasarkan data yang didapatkan pada rekam medis pasien, terdapat 19 jenis pemeriksaan yang dilakukan pada pasien dengan demam berkepanjangan di RS. Cipto Mangunkusumo. Pemilihan pemeriksaan penunjang lanjutan tersebut dilakukan berdasarkan diagnosis kerja namun ternyata tidak seluruh pasien

Tabel 2. Sebaran usia pasien demam berkepanjangan

\begin{tabular}{|c|c|c|c|}
\hline Distribusi & $\leq 2$ tahun & 2 tahun sampai $\leq 6$ tahun & $>6$ tahun \\
\hline \multicolumn{4}{|l|}{ 1. Penyakit infeksi } \\
\hline \multicolumn{4}{|l|}{ Infeksi bakteri } \\
\hline Infeksi saluran kemih & 16 & 5 & 2 \\
\hline Tuberkulosis & 1 & 5 & 1 \\
\hline Leptospirosis & - & - & 1 \\
\hline Tifoid & 2 & 11 & 6 \\
\hline Bakteremia & 11 & 2 & - \\
\hline Meningitis bakterialis & 1 & - & - \\
\hline Bronkopneumonia & 1 & 1 & - \\
\hline Otitis media & 2 & 3 & 1 \\
\hline Enterokolitis & 3 & - & - \\
\hline Zoonosis & - & 1 & - \\
\hline \multicolumn{4}{|l|}{ Infeksi virus } \\
\hline Human imunodefisiensi virus & 1 & - & - \\
\hline Eksantema & - & 1 & - \\
\hline \multicolumn{4}{|l|}{ Infeksi jamur } \\
\hline Kandida & 1 & 1 & - \\
\hline \multicolumn{4}{|l|}{ 2. Keganasan } \\
\hline Neuroblastoma & 1 & - & - \\
\hline Leukemia limfositik akut & - & 4 & - \\
\hline \multicolumn{4}{|l|}{ 3. Penyakit kolagen-vaskular } \\
\hline Reumatoid artritis juvenile sistemik & - & - & 4 \\
\hline Lupus eritematosus sistemik & - & - & 2 \\
\hline Tidak terdiagnosis & 6 & 1 & 2 \\
\hline
\end{tabular}


dengan diagnosis kerja demam berkepanjangan dilakukan seluruh pemeriksaan. Kuman terbanyak yang ditemukan pada biakan darah, biakan urin dan biakan feses adalah masing-masing Staphylococcus epidermidis, Escherichia coli dan Escherichia coli pathogen.

\section{Pembahasan}

Angka kejadian demam berkepanjangan pada anak di Departemen Ilmu Kesehatan Anak FKUI rumah sakit Dr. Cipto Mangunkusumo 2\% dari seluruh pasien yang dirawat selama 3 tahun. Besar angka kejadian ini sesuai dari estimasi dari Long $\mathrm{dkk}^{5}$ yang berkisar 0,5\%-3\%. Kelompok penyakit infeksi merupakan penyebab terbanyak yakni $80 \%$ diikuti oleh penyakit kolagen-vaskular 6\% serta penyakit keganasan 5\%. Hasil yang didapatkan pada penelitian ini sejalan dengan penelitian oleh Pizzo dkk, ${ }^{6}$ Hayani $\mathrm{dkk}^{7}$ serta Steele dkk. ${ }^{8}$ Pada penelitian mereka didapatkan bahwa penyakit infeksi merupakan penyebab terbanyak dari demam berkepanjangan pada anak yakni masingmasing sebesar 52\%, 29\%, dan 67\% .

Kelompok penyakit infeksi mendominasi seluruh lima besar penyebab terbanyak demam berkepanjangan di RS Ciptomangunkusumo, yakni infeksi saluran kemih, demam tifoid, bakteremia, tuberkulosis, serta otitis media. Sejalan dengan penelitian sebelumnya yang menunjukkan bahwa berbagai penyakit infeksi mendominasi penyebab terbanyak demam berkepanjangan pada anak. ${ }^{2}$ Namun penyakitpenyakit yang menjadi penyebab terbanyak demam berkepanjangan pada penelitian ini berbeda dengan penelitian sebelumnya.

Perbedaan penyebab demam berkepanjangan beberapa penelitian dipengaruhi banyak faktor. Dengan berkembangnya ilmu pengetahuan dan teknologi di bidang kedokteran, metode diagnostik dalam mendiagnosis penyakit menjadi semakin baik. ${ }^{1,9,10}$ Penyakit yang semula sulit didiagnosis saat ini menjadi lebih mudah didiagnosis. Faktor lain adalah lokasi dan tempat tinggal pasien. Penyebab demam berkepanjangan tergantung pula pada wilayah geografi tempat pasien tinggal di negara berkembang misalnya, diketahui bahwa kasus malaria, demam tifoid, dan tuberkulosis merupakan kasus terbanyak. ${ }^{2,11}$

Sebagian besar pasien adalah laki-laki, sesuai dengan penelitian Cogulu $\mathrm{dkk}^{3}$ dan Park dkk. ${ }^{12}$ Dari berbagai penelitian sebelumnya, insiden kasus infeksi menurun sejalan dengan bertambahnya usia. Kelompok usia pasien di bawah usia 2 tahun $46 \%$, usia di atas 2 tahun sampai 6 tahun 35\% dan usia di atas 6 tahun $19 \%$, sejalan dengan penelitian dari Pizzo dkk, ${ }^{6}$ Cogulu dkk, ${ }^{3}$ Han dkk, ${ }^{13}$ serta Chiang dkk. ${ }^{14}$

Durasi demam berkepanjangan terbanyak pada pasien yang dirawat di RS Cipto Mangunkusumo adalah antara 8-30 hari, sejalan dengan penelitian dari Cogulu dkk. ${ }^{3}$ Status nutrisi merupakan aspek penting dan perlu diperhatikan pada pasien. Status nutrisi berperan dalam mempengaruhi perjalanan dan prognosis penyakit. Keadaan gizi juga berpengaruh terhadap status imunologi, misalnya pada malnutrisi energi protein sedang/berat terdapat defisiensi / defek imunologi seluler maupun humoral. Sebagian besar pasien memiliki gizi kurang $75 \%$ dari seluruh kasus, gizi buruk 5\% kasus, sejalan dengan penelitian dari Cogulu $\mathrm{dkk}^{3}$ yang menemukan $35 \%$ kasus memiliki berat badan di bawah persentil tiga NCHS.

Seperti diketahui terdapat banyak diagnosis banding dari demam berkepanjangan yang harus disingkirkan. Di lain pihak, waktu pengobatan sampai pada masalah biaya pengobatan menjadi perhatian yang tidak dapat diabaikan. Untuk itu sangat penting dalam memilih pemeriksaan penunjang mana yang paling tepat untuk segera mendapatkan diagnosis akhir penyakit. Pada pemeriksaan laboratorium dasar yang dilakukan, didapatkan hanya pemeriksaan darah rutin serta pemeriksaan hitung jenis yang dilakukan pada seluruh pasien, sedangkan pemeriksaan penunjang dasar lainnya tidak dilakukan pada seluruh kasus. Pada pemeriksaan penunjang lanjutan demam berkepanjangan pada penelitian ini, pemeriksaan biakan darah, biakan urin serta tes tuberkulin merupakan pemeriksaan yang paling sering dilakukan, hanya beberapa kasus saja yang tidak melakukan pemeriksaan tersebut. Hal itu terjadi karena masalah biaya mengingat besarnya biaya dalam melakukan pemeriksaan tersebut cukup besar. Namun bila mengingat hasil diagnosis akhir, yang menunjukkan infeksi saluran kemih, bakteremia serta tuberkulosis menduduki tempat tertinggi sebagai penyebab demam berkepanjangan, maka pemeriksaan tersebut merupakan pemeriksaan penunjang yang sangat diperlukan. Hal ini dikemukakan pula oleh McCarthy $\mathrm{dkk}^{15}$ yang mengemukakan pentingnya dilakukan pemeriksaan penunjang tambahan yang dapat mendiagnosis penyakit yang paling sering menjadi penyebab, tentu berdasarkan indikasinya. 
Beberapa penelitian juga mengemukakan pentingnya pemeriksaan-pemeriksaan penunjang di atas mengingat sangat tingginya insiden penyakit infeksi sebagai penyebab demam berkepanjangan pada anak. ${ }^{6,16}$

Kuman terbanyak pada biakan darah pasien dengan demam berkepanjangan adalah Staphylococcus epidermidis yakni $8 / 13$, berbeda dengan penelitian oleh Berezin dkk, ${ }^{17}$ Ingarfield dkk, ${ }^{18}$ Bandyopadhyay dkk ${ }^{19}$ menemukan kuman Streptococcus pneumoniae. Pada penelitian ini, tidak satu pun dari pasien ditemukan kuman Streptococcus pneumoniae yang menjadi penyebab bakteremia. Bila dibandingkan dengan penyebab bakteremia secara umum pada anak juga didapatkan hasil yang tidak jauh berbeda seperti pada penelitian Babay $\mathrm{dkk}^{20}$ yang menemukan penyebab bakteremia terbanyak pada anak adalah Staphylococcus epidermidis dan Staphylococcus aureus. Dari laporan di negara berkembang seperti Thailand ditemukan kuman E. coli, Streptococcus, Salmonella, Enterobacter spp. dan $S$. aureus merupakan jenis kuman yang paling banyak ditemukan. ${ }^{21}$ Berdasarkan data tersebut, bakteremia pada penelitian ini lebih mendekati bakteremia pada pasien yang tidak mengalami demam berkepanjangan. Hal ini salah satunya dapat menunjukkan bahwa pelayanan kesehatan di negara kita masih belum memadai dibandingkan negara maju karena pemeriksaan biakan masih dinilai mahal sehingga tidak selalu dikerjakan. Pada biakan urin kuman E. coli dan Streptococcus anhemolitikus merupakan penyebab terbanyak yakni masing-masing $9 / 23$ dan $6 / 23$. Hal ini sejalan dengan penyebab tersering infeksi saluran kemih yakni Escherchia coli yang merupakan kuman flora normal pada daerah periuretra dan uretra distal. ${ }^{22}$

Pada biakan feses pasien dengan demam berkepanjangan, Escherichia coli merupakan penyebab terbanyak 2/3 kasus. Hal ini sejalan dengan penelitian Nguyen $\mathrm{dkk}^{23}$ dan Udom $\mathrm{dkk}^{24}$ yang sama-sama menemukan kuman Escherichia coli merupakan penyebab bakteri terbanyak pada biakan feses.

\section{Kesimpulan}

Angka kejadian demam berkepanjangan di RS Cipto Mangunkusumo Jakarta kurun waktu Januari 2004 hingga Maret 2007 sebesar 2\%, sebagian besar kasus laki-laki 59\%. Lima kelompok besar penyebab demam berkepanjangan pada pasien rawat inap adalah infeksi saluran kemih, demam tifoid, bakteremia, tuberkulosis serta otitis media. Sebagian besar pasien berusia di bawah dua tahun $46 \%$ kasus, sebagian besar pasien memiliki gizi kurang, $75 \%$ dari seluruh kasus. Kuman terbanyak yang ditemukan pada biakan darah, biakan urin dan biakan feses adalah masing-masing Staphylococcus epidermidis, Escherichia coli dan Escherichia coli patogen

\section{Daftar Pustaka}

1. Lorin MI, Feigin RD. Fever without source and fever of unknown origin. Dalam: Feigin RD, Cherry JD, Demmler GJ, Kaplan SL, penyunting. Text book of pediatric, infectious diseases. Edisi ke-5. Philadelphia: Elsevier; 2004. h. 825-36.

2. Akpede GO, Akenzua GI. Management of children with prolonged fever of unknown origin and difficulties in the management of fever of unknown origin in children in developing countries. Paediatr Drugs 2001;3:247-62.

3. Cogulu O, Koturuglu G, Kurugol Z. Evaluation 80 children with prolonged fever. Pediatrics 2003;45: 564-9.

4. Teach SJ. Approach to the child with prolonged fever in the pediatric emergency department. Clin Pediatr Emerg Med J 2000;1:157-63.

5. Long SS, Edwards KM. Fever of unknown origin and periodic fever syndromes. Dalam: Long SS, Pickering LK, Prober CG, penyunting. Principles and practice of pediatrics infectious diseases. Edisi ke-2. Philadelphia: Churchill Livingston; 2003. h. 114-20.

6. Pizzo PA, Lovejoy FH, Smith DH. Prolonged fever in children: review of 100 cases. Pediatrics 1975;55:468-73.

7. Hayani A, Mahoney OH, Ferbach DJ. Role of bone marrow examination in the child with prolonged fever. J Pediatr 1990;16:19-20.

8. Steele RW, Jones SM, Lowe BA, Glasier CM. Usefulness of scanning procedures for diagnosis of fever of unknown origin in children. J Pediatr 1991;119:526-30.

9. Arnow PM, Flaherty JP. Fever of unknown origin. Lancet 1997;350:575-80.

10. Akpede GO, Akenzua GI. Aetiology and management of children with acute fever of unknown origin. Paediatr Drugs 2001;3:169-93.

11. Edwin E, Sandra T. Fever of unknown origin at the Santo Tomas University Hospital. Phil J Microbiol Infect Dis 1992;22:35-40. 
12. Park HS, Im SJ, Park SE. Investigation of causes of FUO (fever of unknown origin) in children. Korean J Pediatr 2006;49:1282-86. [Abstrak]

13. Han KS, Yun DJ. Prolonged Fever in Korean Children: Review of 120 cases. J Korean Pediatr Soc. 1979;22:931-9. [Abstrak]

14. Chiang TM, Chang TY. Clinical observation and analysis of febrile children. Zhonghua yi Xue Za Zhi 1993;51:431-5. [Abstrak]

15. McCarthy PL, Bachman DT, Shapiro ED. Fever without apparent source on clinical examination, lower respiratory infections in children, bacterial infections, and acute gastroenteritis and diarrhea of infancy and early childhood. Curr Opin Pediatr 1994;6:105-25.

16. Lohr JA, Hendley JO. Prolonged fever of unknown origin: a record of experiences with 54 childhood patients. Clin Pediatr 1977;16:768-7.

17. Berezin EN, Lazzetti, MA. Evaluation of the incidence of occult bacteremia among children with fever of unknown origin. Braz J Infect Dis 2006;10:396-9.

18. Ingarfield SL, Celenza A, Jacobs IG, Riley TV. Outcomes in patients with an emergency department diagnosis of fever of unknown origin. Emerg Med Australas 2007;19:105-12.
19. Bandyopadhyay S, Bergholte J, Blackwell CD, Friedlander JR, Hennes H. Risk of serious bacterial infection in children with fever without a source in the post-Haemophilus influenzae era when antibiotics are reserved for culture-proven bacteremia. Arch Pediatr Adolesc Med 2002;156:512-7.

20. Babay HA, Twum-Danso K, Kambal AM, Al-Otaib FE. Bloodstream infections in pediatric patients. Saudi Med J 2006;26:1555-61.

21. Leelarasamee A, Chupaprawan C, Chenchittikul M, Udompanthurat. Etiologies of acute undifferentiated febrile illness in Thailand. J Med Assoc Thai 2004; 87:464-72.

22. Hellerstein S. Urinary Tract Infection. Diunduh dari: www.emedicine.com. Diakses tanggal 21 Agustus 2007.

23. Nguyen TV, Le PV. Antibiotic resistance in diarrheagenic Escherichia coliand Shigella strains isolated from children in Hanoi, Vietnam. Antimicrobial Agents and Chemotherapy 2005;49:816-9

24. Udom L, Peter E. Viruses and bacteria in pediatric diarrhea in Thailand: a study of multiple antibioticresistant enteric pathogens. Am J Trop Med Hyg 1981;30:1281-90. 